J. Lake Sci. (湖泊科学), 2018, 30(5): 1319-1331

DOI 10. 18307/2018. 0514

(c) 2018 by Journal of Lake Sciences

\title{
丹江口水库上游梯级开发后产漂流性卵鱼类早期资源及其演变
}

\author{
雷 欢, 谢文星**, 黄道明, 谢山, 唐会元, 陈金生, 杨 钟, 常秀岭, 陈 锋 \\ (水利部中国科学院水工程生态研究所,水利部水工程生态效应与生态修复重点实验室,武汉 430079)
}

\begin{abstract}
摘 要: 2014 年对丹江口水库上游四大家鱼等产漂流性卵鱼类进行早期资源的现状调查,结果表明丹江口水库上游现有 产漂流性卵鱼类共 14 种, 以银鮈、蛇鮈、花斑副沙鳅、粲、蒙古鲌等鱼类为主, 四大家鱼卵 64 粒, 仅占卵数的 $1.02 \%$ 。与 1977 年、1993 年历史调查的产漂流性卵鱼类早期资源数据相比, 产卵场数量减少 6 处, 产卵场的规模和位置发生显著变 化. 丹江口水库上游产漂流性卵鱼类产卵总量下降明显,从 1977 年的近 1745.86 亿粒(尾)下降到 2014 年的 455502.76 万 粒(尾); 其中四大家鱼卵苗径流量下降幅度最为显著, 从 171.27 亿粒(尾)下降到 4295.22 万粒(尾), 四大家鱼卵苗径流 量占鱼类卵苗总径流量的比例也从 $9.81 \%$ 下降到了 $0.94 \%$ 以下.
\end{abstract}

关键词: 丹江口水库;漂流性卵;四大家鱼;产卵场

\section{The early evolution of the fish with pelagic eggs resources in the upstream of Danjiangkou Reservoir after the cascade development}

LEI Huan, XIE Wenxing ** , HUANG Daoming, XIE Shan, TANG Huiyuan, CHEN Jinsheng, YANG Zhong, CHANG Xiuling \& CHEN Feng

( Key Laboratory of Ecological Impacts of Hydraulic-Projects and Restoration of Aquatic Ecosystem of Ministry of Water Resources, Institute of Hydroecology, Ministry of Water Resources and Chinese Academy of Sciences, Wuhan 430079, P.R.China)

Abstract: This study conducted to investigate the early resources of the fish with pelagic eggs in the upstream of Danjiangkou Reservoir in 2014. 14 species were collected and the main species were Squalidus argentatus, Saurogobio dabryi, Parabotia fasciata, Hemiculter leucisclus and Culter mongolicus mongolicus. 64 eggs of the four major Chinese carps were collected, accounted for $1.02 \%$. Compared with the results of 1977 and 1993, the number of the spawning sites reduced by 6 , the size and location of the spawning sites have also changed. The total amount of pelagic eggs in the upstream of Danjiangkou Reservoir decreased from 174.59 billion in 1977 to 4555.03 million in 2014. The eggs of four major Chinese carps also decreased from 17.13 billion to 42.95 million and the proportion decreased from $9.81 \%$ to $0.94 \%$.

Keywords: Danjiangkou Reservoir; pelagic eggs; four major Chinese carps; spawning sites

汉江是长江的重要支流, 也是长江流域四大家鱼自然繁殖的重要河流, 分布有数量较多的产卵场. 丹江 口大坝的建设, 阻碍了汉江上游干支流与汉江中下游的联系, 汉江中下游、长江中下游鱼类无法再上溯至汉 江上游干支流, 其补充作用消失. 汉江上游安康、石泉水电站的建设, 丹江口库尾以上的流水江段缩短至安 康坝下 200 多 $\mathrm{km}$ 的流水江段, 导致丹江口水库库尾以上汉江干流连续性受到影响. 同时, 随着喜河、蜀河梯 级的建设, 梯级阻隔增强, 导致石泉以下流水江段进一步破碎化, 安康至石泉江段形成首位衔接的梯级水 库, 导致产漂流性卵鱼类失去繁殖条件. 丹江口水库产漂流性卵鱼类产卵场分布缩短至蜀河以下汉江江段, 原安康、蜀河产卵场失去产卵繁殖功能, 而白河以下产卵场漂流孵化流程均已不够, 加上南水北调一期工程 丹江口大坝加高,丹江口回水至孤山附近江段, 流水江段进一步缩短, 躴化成活率明显下降.

* 国家重点研发计划项目 (2016YFA0601001) 资助. 2017-09-15 收稿;2018-01-12 收修改稿. 雷欢 (1981 ), 女, 助 理研究员;E-mail:leihappy@ mail.ihe.ac.cn.

** 通信作者;E-mail:xiewx@ mail.ihe.ac.cn. 
在 1977-1993 年分别对汉江上游鱼类资源进行了 2 次较大规模的调查 ${ }^{[1-4]}$, 为探讨汉江上游水电梯级 开发后鱼类资源的演变, 特别是对产漂流性卵鱼类自然繁殖的影响, 2014 年我们对汉江上游产漂流性卵鱼 类早期资源进行了监测, 旨在研究汉江上游水电梯级开发后对产漂流性卵鱼类自然繁殖的生态学效应.

\section{1 材料与方法}

\section{1 丹江口水库上游梯级开发现状}

根据长江水利委员会编制的《汉江干流综合规划》 ${ }^{[5]}$, 汉江洋县黄金峡至丹江口河段共长 $674 \mathrm{~km}$, 落差 大, 水头集中,水力资源丰富, 除安康盆地外,均为深山峡谷, 水能资源开发条件好. 丹江口水库上游共规划 有 8 个梯级,从上往下依次为黄金峡、石泉、喜河、安康、旬阳、蜀河、白河和孤山,各梯级所在位置详见图 1. 目前,已有 4 个梯级建成, 分别是石泉、喜河、安康、蜀河; 在建的梯级有 4 个,依次是黄金峡、旬阳、白河和孤 山. 各梯级开发情况见表 1.

\section{2 早期资源采集}

1.2.1 断面设置 在郧县码头 $\left(32^{\circ} 49^{\prime} 37.52^{\prime \prime} \mathrm{N}, 110^{\circ} 47^{\prime} 47.30^{\prime \prime} \mathrm{E}\right.$, 图 1) 设置监测断面.

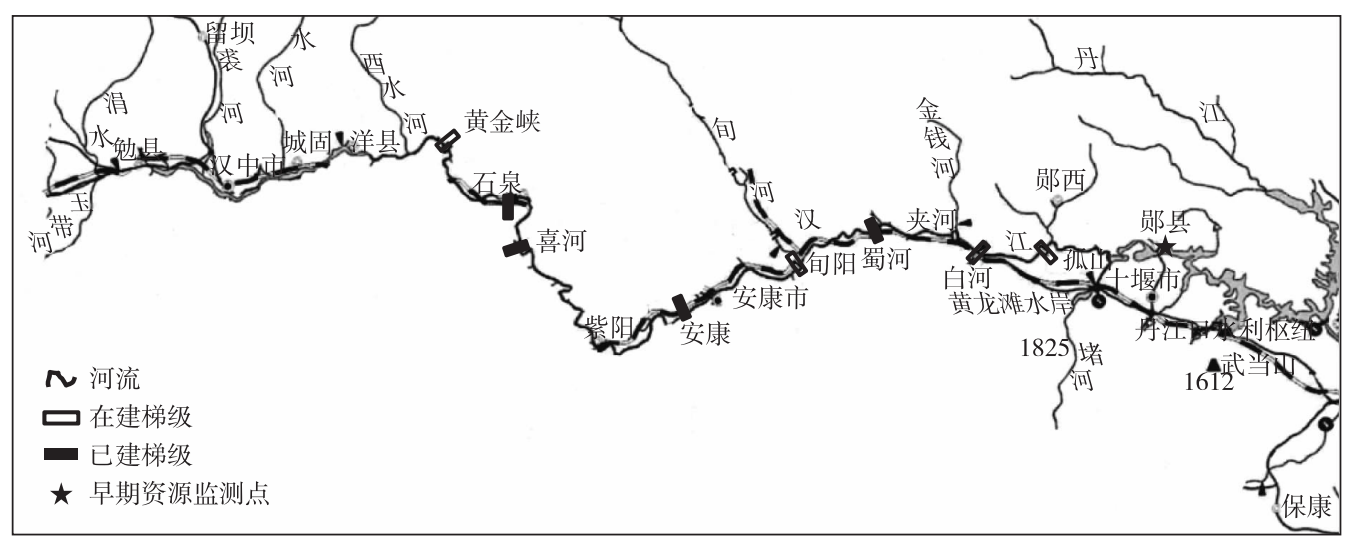

图 1 丹江口水库上游梯级开发示意图 (此为水系示意图, 境界未经实地勘测, 不作为定界依据)

Fig. 1 Distribution of hyolropower stations in the upstream of Danjiangkou Reservoir

表 1 丹江口水库上游已建和在建梯级情况

Tab.1 The cascade development in the upstream of Danjiangkou Reservoir

\begin{tabular}{lcccccccc}
\hline 项目 & 黄金峡 & 石泉 & 喜河 & 安康 & 旬阳 & 蜀河 & 白河 & 孤山 \\
\hline 流域面积 $/$ 万 $\mathrm{km}^{2}$ & 1.80 & 2.34 & 2.52 & 3.57 & 4.24 & 4.94 & 5.11 & 6.04 \\
平均流量 $/\left(\mathrm{m}^{3} / \mathrm{s}\right)$ & 242 & 330 & 352 & 564 & 635 & 720 & 734 & 778 \\
正常蓄水位 $/ \mathrm{m}$ & 450 & 410 & 362 & 330 & 240 & 217.3 & 195.50 & 179 \\
死水位 $/ \mathrm{m}$ & 440 & 400 & 360 & 300 & 239 & 215 & 193.50 & 176.77 \\
调节库容 $/$ 亿 $\mathrm{m}^{3}$ & 0.69 & 1.67 & 0.20 & 16.23 & 0.46 & 0.26 & 0.22 & 0.24 \\
调节性能 & 日 & 季 & 日 & 不完全年 & 日 & 日 & 日 & 日 \\
建设地点 & 洋县黄金 & 石泉县 & 石泉县 & 安康市 & 旬阳县 & 旬阳县 & 白河县 & 郧西县 \\
& 峡镇 & & 喜河镇 & 汉滨区 & & 蜀河镇 & & 孤山村 \\
建成时间 & 在建 & 1975 年 & 2007 年 & 1995 年 & 在建 & 2016 年 & 在建 & 在建 \\
\hline
\end{tabular}

1.2.2 样本采集 监测方法按照《内陆水域渔业自然资源调查手册》 ${ }^{[6]}$, 同时参照易伯鲁等 ${ }^{[7]}$ 、长江四大家鱼 产卵场调查队 ${ }^{[8]}$ 、刘乐和等 ${ }^{[9]}$ 的方法进行, 产漂流性卵鱼类胚胎发育时序参照相关文献 ${ }^{[10-12]}$. 对采集的鱼卵 立刻进行分类, 记录发育期, 通过观察及测量卵径、胚体长、卵色泽、发育期及其他特征进行鉴定. 每个断面 设置左、中、右 3 个采样点, 每个采样点采集上、中、下水层样品. 表层样品采集用弶网, 网口半圆形, 半径 $0.5 \mathrm{~m}$, 
面积 $0.3927 \mathrm{~m}^{2}$, 中层和底层样品采集用圆雉网, 网口半径 $0.35 \mathrm{~m}$, 面积 $0.3848 \mathrm{~m}^{2}$. 流速使用旋桨式流速仪测 定. 监测 5-9 月的所有洪峰过程, 每个洪峰过程连续监测, 每天监测 $12 \mathrm{~h}$, 监测时段为 10:00-13:00、 $16: 00-19: 00 、 22: 00-1: 00$ 和 $4: 00-7: 00$. 监测时每隔 $0.5 \mathrm{~h}$ 收集一次样品.

1.2 .3 卵苗鉴定 采集到的四大家鱼鱼卵统一就地培育到尾芽形成期至出膜前期进行鉴定, 对四大家鱼鱼 苗直接鉴定. 无法鉴定的鱼卵和鱼苗，就地培育直到能鉴定种类为止.

\section{3 水文测定与资料}

使用旋桨式流速仪测定采集断面左、中、右站位及采集网口江水的流速. 水文数据取自汉江上游白河水 文站.

\section{4 产卵江段推算方法}

1.4.1 产卵江段推算方法 产卵场的位置依据采集鱼卵的发育期和当时水流速度进行推算, 公式为: $S=V \cdot T$, $S$ 为鱼卵的漂流距离, $V$ 为江水平均流速, $T$ 为当时水温条件下肧胎发育经历的时间.

1.4.2 断面系数的计算 根据断面上每个采集点表、中、底 3 个水层样品的鱼卵和鱼苗的密度,计算断面上所 有样品的平均密度, 以之除以定点采集点的鱼卵和鱼苗的密度, 即可得出断面系数.

断面上所有采集点的平均密度为:

则断面系数为:

$$
d_{\mathrm{p}}=\left(\sum_{j=1}^{n} d_{j}\right) / n
$$

$$
c_{i}=d_{\mathrm{p}} / d_{j}
$$

式中, $d_{\mathrm{p}}$ 为断面上所有采集点鱼卵和鱼苗的平均密度, $d_{j}$ 为定点采集点的鱼卵和鱼苗的密度, $n$ 为采集点数, $c_{i}$ 为断面系数.

1.4.3 鱼苗径流量的计算 每次采集时的卵苗径流量为:

非采集期间的卵苗径流量为:

$$
m_{i}=q_{i} \cdot d_{i} \cdot c_{i} \cdot t_{i}
$$

$$
m_{i, i+1}=\left(m_{i} / t_{i}+m_{i+1} / t_{i+1}\right) T_{i, i+1 / 2}
$$

总卵苗径流量为:

$$
y=\sum m_{i}+\sum m_{i, i+1}
$$

式中, $m_{i}$ 为第 $i$ 次采集期间的鱼卵、鱼苗流量 (粒或尾), $q_{i}$ 为第 $i$ 次采集期间的水流量 $\left(\mathrm{m}^{3} / \mathrm{s}\right), d_{i}$ 为第 $i$ 次采 集的鱼卵、鱼苗密度 $\left(\right.$ 粒 $/ \mathrm{m}^{3}$ 或尾 $\left./ \mathrm{m}^{3}\right), c_{i}$ 为第 $i$ 次采集的断面系数, $t_{i}$ 为第 $i$ 次采集的时间 $(\mathrm{min}), m_{i, i+1}$ 为第 $i$ 和 $i+1$ 次采集时间间隔内鱼卵、鱼苗流量 (粒或尾), $T_{i, i+1}$ 为第 $i$ 和 $i+1$ 次采集时间间隔 (min).

\section{2 结果}

\section{1 苗 (卵) 汛与水文状况的关系}

2014 年早期资源野外监测期间,有 2 次明显 洪峰过程, 洪峰上涨时间分别为 9月 $10-13$ 日和 17-19 日（图 2), 其中 9 月 11-12 日出现四大家 鱼苗汛.

\section{2 鱼类的组成及产卵类型}

2014 年采样期间共采获漂流性鱼卵 6253 粒 (表 2), 鱼卵性状及类型见表 3. 从表 2 中可以看 出, 丹江口库尾以上汉江干流产漂流性鱼卵鱼类 组成以银鮈、蛇鮈、花斑副沙鱾、粲、蒙古鲌等鱼类 为主, 四大家鱼卵 64 粒, 占卵数的 $1.02 \%$.

从表 3 中可以看出, “四大家鱼” 中的青鱼、草 鱼、鲢以及鰔、犁头鲀的卵径较大, 吸水后可达到

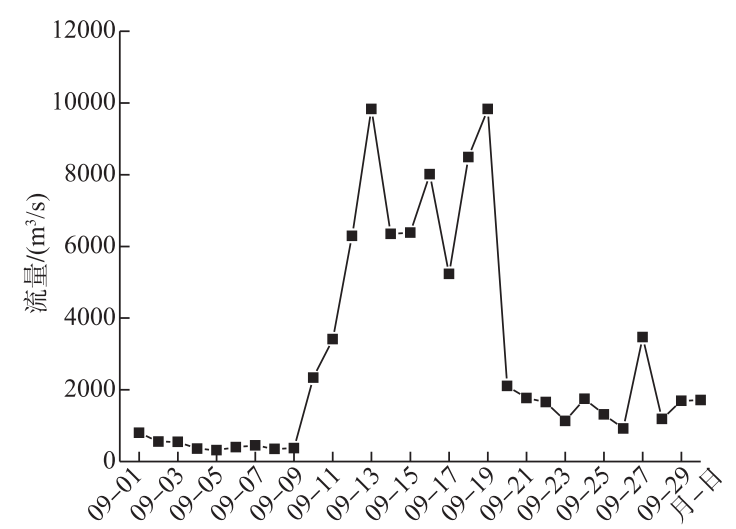

图 2 白河 2014 年 9 月流量日变化

Fig.2 Daily flow rate of Baihe River in September of 2014 
4.8 6.5 mm; 赤眼鳟、花斑副沙䱊、蛇鮈等鱼类的卵径稍小, 达到 $3.2 \sim 4.5 \mathrm{~mm}$, 卵黄色彩为策黄, 是典型的漂 流性卵. 银鮈、蒙古鲌、尧咀鲌等鱼类产弱粘性卵, 卵膜径有大有小 $(2.5 \sim 5.1 \mathrm{~mm})$, 受精卵在浑浊的河水中易 脱落,随流水漂流发育. 没有采集到浮性卵.

表 2 丹江口库尾以上产漂流性卵鱼类种类组成

Tab.2 Composition of the fish with pelagic eggs in the upstream of Danjiangkou Reservoir

\begin{tabular}{|c|c|c|}
\hline 种类 & 卵数量/粒 & 比例 $/ \%$ \\
\hline 鲢 Hypophthalmichthys molitrix & 41 & 0.66 \\
\hline 草鱼 Ctenopharyngodon idellus & 18 & 0.29 \\
\hline 青鱼 Mylopharungodon piceus & 5 & 0.08 \\
\hline 犁头鳅 Lepturichthys fimbriata & 12 & 0.19 \\
\hline 蛇鮈 Saurogobio dabryi & 1465 & 23.43 \\
\hline 花斑副沙鲉 Parabotia fasciata & 714 & 11.42 \\
\hline 中华沙鳅 Botia (Sinibotia) superciliaris & 135 & 2.16 \\
\hline 银鮈 Squalidus argentatus & 2818 & 45.07 \\
\hline 蒙古鲌 Culter mongolicus mongolicus & 246 & 3.93 \\
\hline 翘嘴鲌 Culter alburnus & 129 & 2.06 \\
\hline 粲 Hemiculter leucisclus & 447 & 7.15 \\
\hline 鱤 Elopichthys bambusa & 11 & 0.18 \\
\hline 赤眼䲡 Squaliobarbus curriculus & 16 & 0.26 \\
\hline 银飘 Pseudolaubuca sinensis & 196 & 3.13 \\
\hline 合计 & 6253 & 100 \\
\hline
\end{tabular}

表 3 丹江口库尾以上产漂流性卵鱼类鱼卵性状及类型

Tab.3 Characteristics and types of the fish with pelagic eggs in the upstream of Danjiangkou Reservoir

\begin{tabular}{|c|c|c|c|c|c|}
\hline \multirow{2}{*}{ 种类 } & \multicolumn{3}{|c|}{ 早期鱼卵性状 } & \multicolumn{2}{|c|}{ 漂流性卵类型 } \\
\hline & 吸水膨胀膜径 $/ \mathrm{mm}$ & 卵径/mm & 卵黄色彩 & 典型类 & 微粘类 \\
\hline 青鱼 & $5.0 \sim 6.0$ & $1.7 \sim 1.8$ & 酪黄 & + & \\
\hline 草鱼 & $5.0 \sim 5.8$ & $1.7 \sim 1.9$ & 䉝黄 & + & \\
\hline 鲢 & $4.8 \sim 5.9$ & $1.6 \sim 1.8$ & 浅枇杷黄 & + & \\
\hline 鱤 & $5.0 \sim 6.5$ & $1.8 \sim 2.0$ & 酪黄 & + & \\
\hline 赤眼鳟 & $3.8 \sim 4.5$ & $1.3 \sim 1.5$ & 䉝黄 & + & \\
\hline 花斑副沙鲀 & $3.9 \sim 4.5$ & $1.4 \sim 1.5$ & 枇杷黄 & + & \\
\hline 犁头鳅 & $5.0 \sim 5.8$ & $1.7 \sim 1.8$ & 肉红 & + & \\
\hline 蒙古鲌 & $4.5 \sim 5.0$ & $1.5 \sim 1.6$ & 策黄 & & + \\
\hline 翅咀鲌 & $4.5 \sim 5.1$ & $1.4 \sim 1.5$ & 酪黄 & & + \\
\hline 银鮈 & $2.5 \sim 3.8$ & $1.0 \sim 1.2$ & 杏仁黄 & & + \\
\hline 蛇鮈 & $3.2 \sim 4.4$ & $1.0 \sim 1.1$ & 策黄 & + & \\
\hline 粲 & $2.3 \sim 3.1$ & $1.1 \sim 1.3$ & 䉝黄 & & + \\
\hline
\end{tabular}

\section{3 产卵场分布}

根据产卵径流公式计算分析, 丹江口水库库尾以上汉江干流产漂流性卵鱼类的产卵场有 4 个, 见表 4 和 图 3 .

1) 前房产卵场: 自塔峪滩至崔家河约 $18 \mathrm{~km}$ 江段,为原肠早期一肌节出现期受精卵推算得出的.

2) 天河口产卵场: 距上方产卵场约 $38 \mathrm{~km}$, 汉江干流天河口至晏家棚江段, 长约 $7 \mathrm{~km}$. 为尾芽期一尾泡 出现期受精卵推算得出.

3 ) 白河产卵场: 距上方产卵场约 $17 \mathrm{~km}$, 位于汉江白河镇至将军河口长约 $14 \mathrm{~km}$ 湘江江段. 为肌肉效应 
期一心脏原基期受精卵推算得出.

4) 夹河产卵场: 距上方产卵场约 $11 \mathrm{~km}$, 自汉江干流冷水河口至夹河镇长约 $16 \mathrm{~km}$ 江段, 为心脏搏动 期一肌出膜前期受精卵推算得出.

表 4 丹江口库尾以上产漂流性卵鱼类产卵场分布

Tab.4 Distribution of the fish with pelagic eggs in the upstream of Danjiangkou Reservoir

\begin{tabular}{ccccccc}
\hline 序号 & 名称 & 发育期 & 距受精时间 $/ \mathrm{h}$ & 漂流距离 $/ \mathrm{km}$ & 范围 & 长度 $/ \mathrm{km}$ \\
\hline 1 & 前房产卵场 & 原肠早期一肌节出现期 & $13.5 ~ 9$ & $49 \sim 31$ & 塔峪滩一崔家河 & 18 \\
2 & 天河口产卵场 & 尾芽期一尾泡出现期 & $21.5 \sim 20$ & $86 \sim 79$ & 天河口一晏家棚 & 7 \\
3 & 白河产卵场 & 肌肉效应期一心脏原基期 & $27.5 ~ 24$ & $109 \sim 95$ & 白河镇一将军河口 & 14 \\
4 & 夹河产卵场 & 心脏搏动期一出膜前期 & $38 \sim 34$ & $151 \sim 135$ & 冷水河口一夹河镇 & 16 \\
\hline
\end{tabular}

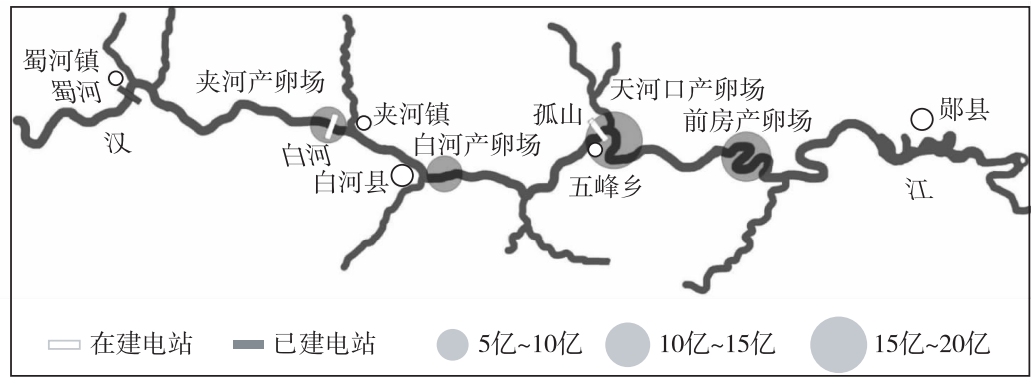

图 3 丹江口库尾以上产漂流性卵鱼类产卵场分布示意图

Fig.3 Distribution of the fish with pelagic eggs in the upstream of Danjiangkou Reservoir

\section{4 产卵场规模}

根据产卵径流公式计算,计算出 2014 年 9 月采样期 (采样时段: 2014 年 9 月 15-20日) 产卵规模为 455502.76 万粒. “四大家鱼”产卵规模为 4295.22 万粒,占采样期产卵规模的 $0.94 \%$.

主要经济鱼类 (银鮈、蛇鮈、蒙古鲌、赤眼䲡和粲五种) 产卵规模为 427261.93 万粒, 占采样期产卵规模的 $91.77 \%$; 其他鱼类犁头鲉、花斑副沙䲝、银飘和鱤等产卵规模为 33183.49 万粒,占采样期产卵规模的 $7.30 \%$. 各产卵场的具体规模及种类组成见表 5 和表 6.

1 ) 前房产卵场: 产漂流性卵鱼类产卵量 134168.90 万粒, 占采样期总产卵量的 $29.46 \%$, 是丹江口库尾以 上汉江干流产漂流性卵鱼类产卵规模较大的产卵场. “四大家鱼” 产卵量较大, 为 2265.74 万粒, 占该产卵场 产卵规模的 $1.69 \%$; 银鮈、蛇鮈、赤眼鳟、粲为该产卵场主要种类,产卵量为 102247.80 万粒,占该产卵场产卵 规模的 $76.21 \%$.

2) 天河口产卵场: 产漂流性卵鱼类产卵量 170828.01 万粒, 占采样期总产卵量的 $37.50 \%$, 是丹江口库尾 以上汉江干流产漂流性卵鱼类产卵规模最大的产卵场. “四大家鱼” 青鱼、草鱼和鲢产卵量为 1283.53 万粒, 占该产卵场产卵规模的 $0.75 \%$; 银鮈、蛇鮈、赤眼鳟、粲为该产卵场的主要产卵种类, 产卵量为 152144.41 万 粒, 占该产卵场产卵规模的 $89.06 \%$.

3) 白河产卵场:产漂流性卵鱼类产卵量 80305.26 万粒,占采样期总产卵量的 $17.63 \%$, 是丹江口库尾以 上汉江干流产漂流性卵鱼类产卵规模较小的产卵场. “四大家鱼” 产卵量最小, 为 88.54 万粒, 仅有鲢在此产 卵, 占该产卵场产卵规模的 $0.11 \%$. 银鮈、蛇鮈、粲 3 种鱼产卵量为 67911.14 万粒, 合计占该产卵场产卵规模 的 $84.57 \%$,为该产卵场的主要产卵种类.

4) 夹河产卵场:产漂流性卵鱼类产卵量 70200.56 万粒, 占采样期总产卵量的 $15.41 \%$, 是丹江口库尾以 上汉江干流产漂流性卵鱼类产卵规模最小的产卵场. “四大家鱼” 产卵量为 657.41 万粒, 占该产卵场产卵规 模的 $1.03 \%$; 银鮈、蛇鮈、蒙古鲌、粲为该产卵场的主要产卵种类, 产卵量为 61974.16 万粒, 占该产卵场产卵 规模的 $88.29 \%$. 
表 5 丹江口库尾以上产漂流性卵鱼类 在各产卵场的比重（\%)

Tab.5 Proportion of the fish with pelagic eggs in the upstream of Danjiangkou Reservoir

\begin{tabular}{lcccc}
\hline \multirow{2}{*}{ 种类 } & \multicolumn{4}{c}{ 产卵场 } \\
\cline { 2 - 5 } & 前房 & 天河口 & 白河 & 夹河 \\
\hline 鲢 & 50.85 & 30.01 & 3.14 & 15.99 \\
草鱼 & 60.47 & 21.41 & 0.00 & 18.12 \\
青鱼 & 42.40 & 57.60 & 0.00 & 0.00 \\
犁头鲀 & 40.91 & 46.54 & 4.52 & 8.02 \\
蛇鮈 & 36.79 & 46.39 & 7.97 & 9.86 \\
赤眼䲡 & 36.17 & 32.72 & 21.31 & 9.80 \\
中华沙鳅 & 13.75 & 46.81 & 18.50 & 20.93 \\
银鮈 & 25.93 & 28.75 & 25.21 & 20.11 \\
蒙古鲌 & 36.86 & 29.60 & 15.92 & 17.62 \\
翘嘴鲌 & 27.47 & 38.72 & 22.16 & 11.65 \\
粲 & 33.15 & 32.99 & 16.94 & 16.93 \\
鱤 & 44.08 & 38.54 & 0.00 & 17.38 \\
花斑副沙鳅 & 25.46 & 64.26 & 5.18 & 5.09 \\
银飘 & 39.44 & 26.26 & 21.52 & 12.78 \\
\hline
\end{tabular}

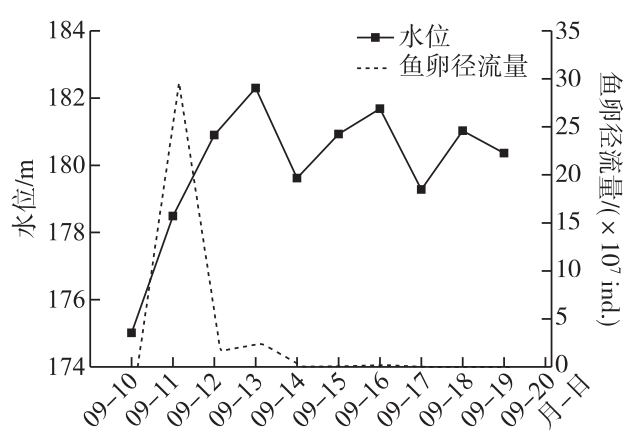

图 4 白河水位与产漂流性卵 鱼类产卵或鱼卵径流量的关系

Fig.4 Relationship between water level in Baihe River section and reproduction activity of the fish with pelagic eggs or egg amount of runoff

\section{5 产漂流性卵鱼类早期资源的空间分布}

从表 4、5 中可以看出丹江口水库库尾以上汉江干流 鱼类早期资源的空间分布, 银鮈、蛇鮈、蒙古鲌、粲、赤眼 䲡等主要经济鱼类在 4 个产卵场均有分布, 但它们在各 个产卵场的比重有所不同. 四大家鱼中鲢在 4 个产卵场 均有分布, 其中前房产卵场比率最大, 占其产卵量的 $50.85 \%$; 草鱼产卵场除白河产卵场没有分布外, 其余 3 个产卵场均有分布, 并以前房产卵场比率最大, 占其产 卵量的 $60.47 \%$; 而青鱼产卵场仅在前房、天河口 2 个产 卵场有分布,分别占其产卵量的 $42.40 \%$ 和 $57.60 \%$.

银鮈在 4 个产卵场分布较为均匀, 比率在 $20.11 \%$ $28.75 \%$ 之间, 蛇鮈、蒙古鲌、粲、赤眼鳟主要分布在前房 和天河口 2 个产卵场; 鳡鱼和犁头鱾作为典型的产漂流 性卵鱼类, 其产卵场也主要分布在前房和天河口 2 个产 卵场(表 $5 、 6$ ).

\section{3 分析与讨论}

\section{1 产漂流性卵鱼类的产卵规模和水文条件的相关性分析}

产漂流性卵鱼类的繁殖活动是在江中涨水期间进 行的 ${ }^{[2]}$. 在鱼类繁殖季节, 江河的涨水过程包含着水位 升高、流量增大、流速加快、流态紊乱及透明度减小等多 种水文因素的变化. 而在这些水文因素中, 对鱼类繁殖 活动起主要促进作用的是流速的增大. 流速的变化可以 简易地用江河水位升降来反映.

江水水位涨幅与产漂流性卵鱼类的产卵量有一定的 相关性(表 7). 一般来说, 发洪水的第 2 天, 产漂流性卵鱼 类才开始产卵 ${ }^{[2-5]}$. 汉江上游发洪多在秋季, 且时间短涨幅 迅速, 产漂流性卵鱼类主要在水位上涨时产卵, 从图 2、图 4 可以看出, 9 月 10-14 日是汉江上游第 1 次洪水过程, 发洪水的第 1 天 (9月 10 日), 水位迅速上涨, 没有采集到 鱼卵; 发洪水第 2 天 (9 月 11 日), 水位继续上涨, 收集到 的鱼卵最多, 此日水位上涨幅度最大 (表 7), 比前一日上 涨 $3.48 \mathrm{~m}$. 随后 9 月 $15-16$ 日和 9 月 $18-19$ 日, 汉江上 游出现小洪水, 相对于第 1 次水位变幅不大, 没有采集到 鱼卵. 可见,产漂流性卵鱼类的产卵出现在水位上升阶段,

且江水涨幅越大, 产漂流性卵鱼类的产卵量往往越大.

\section{2 产漂流性卵鱼类早期资源演变}

从多次产漂流性卵鱼类产卵场调查的结果看, 丹江口水库产漂流性卵鱼类产卵场主要分布于丹江口库 尾以上汉江干流, 1977 年的调查表明 ${ }^{[2]}$, 郧县以上汉江干流分布约 10 个产漂流性卵鱼类产卵场, 从漂流流 程来看, 效果最好的为漩窝、洞河镇、安康和蜀河镇产卵场, 基本能够保证发育至具有自主游泳能力的仔鱼 所需的流速和流程, 前房和天河产卵场虽然规模大, 但漂流流程短, 孵化成活率非常有限. 随着汉江上游水 电开发, 丹江口大坝加高, 汉江上游生境发生了显著变化, 相应产漂流性卵鱼类产卵场及其早期资源也发生 了相应的变化, 变化过程可以大致分成 3 个阶段, 即: 丹江口水库建成后至安康水库建成前、安康水库建成 后至丹江口大坝加高前、丹江口大坝加高后. 


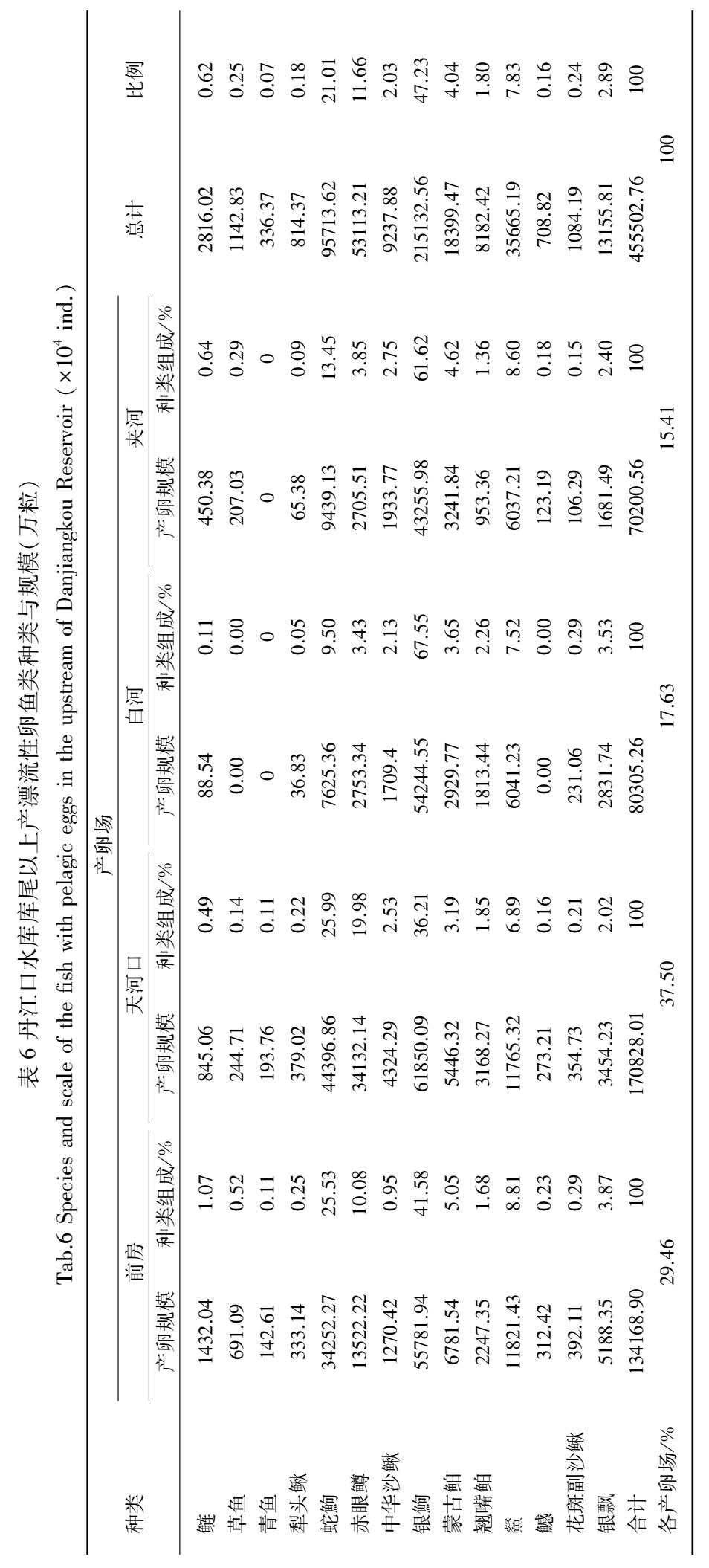


表 7 水位涨幅与产漂流性卵鱼类产卵量的关系

Tab.7 Relationship between rising size in water level and egg production of the fish with pelagic eggs

\begin{tabular}{lrrr}
\hline 日期(月-日) & 水位/ $\mathrm{m}$ & $\begin{array}{r}\text { 水位比前 } \\
\text { 日涨幅/ } \mathrm{m}\end{array}$ & $\begin{array}{r}\text { 产卵量/ } \\
\text { (粒/d) }\end{array}$ \\
\hline $09-09$ & 172.43 & 0.16 & 0 \\
$09-10$ & 175.01 & 2.58 & 0 \\
$09-11$ & 178.49 & 3.48 & 6991 \\
$09-12$ & 180.90 & 2.41 & 335 \\
$09-13$ & 182.30 & 1.40 & 170 \\
$09-14$ & 179.62 & -2.68 & 1 \\
$09-15$ & 180.93 & 1.31 & 7 \\
$09-16$ & 181.68 & 0.75 & 9 \\
$09-17$ & 179.28 & -2.40 & 0 \\
$09-18$ & 181.03 & 1.75 & 0 \\
$09-19$ & 180.36 & -0.67 & 0 \\
\hline
\end{tabular}

3.2.1 产卵场数量减少, 位置发生变化 丹江口水库 建成后, 勋县以上汉江干流分布有产漂流性卵鱼类产 卵场 10 个(表 8 ), 安康水电站建成后, 安康坝址以上 的漩窝、洞河镇产卵场消失, 安康产卵场受大坝建设 及电站泄水影响, 位置下移, 前房、天河产卵场呈合并 的趋势, 界限变得不明显, 肖家湾产卵场产卵活动消 失. 安康坝下蜀河电站建成后, 安康产卵场消失, 蜀河 产卵场坝上部分被淹没, 坝下部分受泄水影响, 产卵 场下移. 现状调查结果表明 (表 8 ), 目前安康电站以 下丹江口库尾以上汉江干流产漂流性卵鱼类产卵场 主要为夹河、白河、天河和前房, 肖湾、郧县产卵场在 洪水初期有部分产卵活动, 随着来水量增加, 丹江口 库水位的抬高, 水流变缓, 不再具备产卵的水文水动 力学条件, 其产卵场仅能发挥部分功能. 随着南水北 调运行后, 丹江口水库抬高水位运行, 旬阳、白河电站 的建成运行,该河段可能仅夹河河口至将军河河口、 天河口江段具备产漂流性卵鱼类产卵繁殖的条件, 前

房产卵场估计受丹江口水位抬高的影响, 仅部分江段能够繁殖, 肖湾、郧县产卵场消失.

表 81977 、1993 和 2014 年丹江口水库上游产漂流性卵鱼类产卵场分布

Tab.8 Distribution of the fish with pelagic eggs in the upstream of Danjiangkou Reservoir in 1977, 1993 and 2014

\begin{tabular}{|c|c|c|c|c|}
\hline 调查年份 & 名称 & 范围 & 长度 $/ \mathrm{km}$ & 相隔距离 $/ \mathrm{km}$ \\
\hline \multirow[t]{11}{*}{1977 年 } & 漩窝 & 汉阳坪一漩窝 & 11 & 距石泉 44.5 \\
\hline & 洞河镇 & 洞河一临河 & 16 & 67 \\
\hline & 安康 & 火石崖一安康 & 20.5 & 38.5 \\
\hline & 蜀河镇 & 展河源一界牌石 & 16.5 & 80.5 \\
\hline & 爽河镇 & 冷水河口一夹河镇 & 15.5 & 16 \\
\hline & 白河 & 白河镇一将军河口 & 16 & 11.5 \\
\hline & 天河口 & 天河一晏家棚 & 7.5 & 18.5 \\
\hline & 前房 & 塔峪滩一崔家河 & 13 & 17 \\
\hline & 肖家湾 & 刘家湾一油坊沟 & 5.5 & 9.5 \\
\hline & 郧县 & 金岗山一郧县 & 8 & 9 \\
\hline & & 调查江段(石泉一郧县) & & 441.5 \\
\hline \multirow[t]{6}{*}{1993 年 } & 安康 & 安康一前家岭 & 17 & 距安康 1.0 \\
\hline & 蜀河口 & 展河源一界牌石 & 16.5 & 63.5 \\
\hline & 白河 & 冷水河口一羊尾 & 37.5 & 16 \\
\hline & 前房 & 天河口一崔家河 & 37.5 & 24 \\
\hline & 郧县 & 金岗山一郧县汉江大桥 & 8 & 25 \\
\hline & & 调查江段( 安康一郧县) & & 246.0 \\
\hline \multirow[t]{4}{*}{2014 年 } & 夹河 & 冷水河口一夹河镇 & 16 & \\
\hline & 白河 & 白河镇一将军河口 & 14 & \\
\hline & 天河口 & 天河口一晏家棚 & 7 & \\
\hline & 前房 & $\begin{array}{l}\text { 塔峪滩一崔家河 } \\
\text { 调查江段(郧县) }\end{array}$ & 18 & \\
\hline
\end{tabular}


产卵量下降幅度最为显著, 仅为 1977 年四大家鱼产卵量的 $4.18 \%$, 其他经济鱼类如赤眼䲡、鳊、铜鱼等鱼类 产卵量占鱼类产卵总量的 $3.80 \%$, 为 1977 年其他经济鱼类产卵量的 $29.13 \% .1977$ 年小型鱼类产卵量占总产 卵量的 $84.85 \%, 1993$ 年上升至 $92.2 \%$; 而其他经济鱼类如赤眼鳟、鳊、铜鱼产卵量比例有所下降, 从 1977 年 的 5.34\%下降到 1993 年的 3.80\% ; 四大家鱼等大型个体产卵量的急剧下降,从 1977 年的 $9.81 \%$ 下降到 1993 年的 $1.00 \%$, 表明丹江口水库鱼类小型化趋势越来越明显 (表 9 ).

现状调查表明,2014 年 9 月 10-20日洪峰周期丹江口郧县至蜀河电站产漂流性卵鱼类产卵场的规模 为 455502.76 万粒, 仅为 1993 年的 $6.39 \%$, 虽然产卵量与洪水过程关系密切, 汉江近两年为枯水年, 发洪时 间晚, 洪峰流量小, 现场调查的早期资源量代表性不强, 但下降的趋势明显. 同时, 四大家鱼早期资源仅在前 房和天河口产卵场采到少量草鱼、鲢受精卵,所占漂流性卵产卵总量的比例不超过 $1.00 \%$, 小型鱼类占据了 绝对优势 (表 9).

表 9 丹江口水库上游鱼类卵苗径流量的演变

Tab.9 Evolution of eggs and fry in the upstream of Danjiangkou Reservoir

\begin{tabular}{|c|c|c|c|c|c|c|}
\hline \multirow{2}{*}{ 项目 } & \multicolumn{2}{|c|}{1977 年 } & \multicolumn{2}{|c|}{1993 年 } & \multicolumn{2}{|c|}{2014 年 } \\
\hline & 数量/亿粒 (尾) & 比例 $/ \%$ & 数量/亿粒 (尾) & 比例 $/ \%$ & 数量/万粒 (尾) & 比例 $/ \%$ \\
\hline 产卵总量 & 1745.86 & & 712.43 & & 455502.76 & \\
\hline 四大家鱼 & 171.27 & 9.81 & 7.16 & 1.00 & 4295.22 & 0.94 \\
\hline 其他经济鱼类 & 93.16 & 5.34 & 27.14 & 3.80 & 33183.49 & 7.30 \\
\hline 小型鱼类 & 1481.43 & 84.85 & 656.53 & 92.20 & 427261.93 & 91.77 \\
\hline
\end{tabular}

\section{3 影响鱼类早期资源变化的原因分析}

3.3.1 水利工程 目前, 随着汉江上游黄金峡、安康、旬阳、白河等梯级电站的建设运行, 导致汉江上游水文情 势发生变化,产卵孵化的水文水力学条件难以满足需求, 汉江上游产漂流性卵鱼类的产卵场规模锐减.

1977 年早期资源调查时, 丹江口水库库尾以上干流没有建设拦河枢纽工程, 支流的水利水电开发也比 较少, 汉江上游水文过程依然维持自然状态. 1993 年早期资源调查时, 安康水电站已建成运行, 安康水电站 属不完全年调节, 调节库容为 16 亿 $\mathrm{m}^{3}$, 水库的调节作用使洪峰过程弱化, 不仅淹没了安康坝上两个产卵场, 安康坝下安康产卵场也受到安康水文情势的变化, 产卵规模很有限, 由于支流开发程度较低, 相应地蜀河、 夹河、白河以、将军河、天河的汇人, 缓解了安康水库调节的影响, 丹江口库尾以上汉江干流产漂流性卵鱼类 早期资源量虽比 1977 年调查明显下降, 但仍达到了 170 多亿粒. 同时, 安康大坝的建成, 受精卵漂流流程缩 短, 安康大坝距郧县 $219 \mathrm{~km}$ 左右, 郧县以下不到 $30 \mathrm{~km}$, 库尾流速就会低于 $0.2 \mathrm{~m} / \mathrm{s}$ 漂流性卵漂流流速, 若按 汉江平均流速 $1 \mathrm{~m} / \mathrm{s}$ 计算, 四大家鱼等漂流性卵孵化距离约为 $170 \mathrm{~km}$, 从 1993 年产卵场的分布情况看, 蜀河 口产卵场距安康大坝接近 $100 \mathrm{~km}$, 即蜀河、安康两个产卵场能够顺利漂流孵化外, 其他产卵场漂流孵化流程 均不足, 未孵化的鱼类胚胎沉人水库库底, 成活率很低.

随着石泉、蜀河等水电站以及支流水利水电的开发, 干支流水库调节能力进一步增强, 水文情势发生明 显变化. 从 2014 年鱼类早期资源的监测情况看, 丹江口库尾以上汉江干流表现出洪峰过程坦化, 甚至消失, 发洪时间推迟等典型特点. 2014 年仅在 9 月份发生了 1 次较为集中的洪水过程,整个 5-8 月份没有明显的 洪峰过程. 同时, 由于蜀河水电站的建设, 蜀河产卵场遭到破坏, 丹江口库尾以上汉江干流连续的流水江段 进一步缩短, 受精卵漂流孵化流程进一步缩短.

目前, 汉江上游干流在建水利水电过程有引汉济渭、旬阳水电站、白河水电站等工程, 丹江口大坝加高 蓄水, 南水北调工程正式运行, 随着这些水利水电工程的建设运行, 汉江上游水文情势将进一步发生变化, 产漂流性卵鱼类产卵场将退缩至夹河河口以下, 而丹江口回水将达到孤山坝址以上, 即使鱼类繁殖期实施 洪限水位运行, 回水也在堵河河口韩家洲以上, 夹河河口以下流水河段的长度也仅在 $80 \mathrm{~km}$ 左右, 产卵场面 积萎缩, 受精卵漂流孵化流程缩短, 产卵场产卵效率将大幅度丧失.

丹江口大坝建成后, 汉江中下游的水文情势也发生了较大变化, 汉江中下游四大家鱼等产漂流性卵苗 径流量下降明显 ${ }^{[14-15]}$, 由 $5 \times 10^{8}$ 粒 (尾)下降到不足 $1 \times 10^{8}$ 粒( 尾), 所占鱼类卵苗总径流量的比例也从 $19.0 \%$ 
下降到了 $1 \%$ 以下. 从长江干流来看, 早在葛洲坝水利枢纽的兴建过程中, 易伯鲁等 ${ }^{[7]}$ 、长江四大家鱼产卵场 调查队 ${ }^{[8]}$ 、刘乐和等 ${ }^{[9]}$ 就报道过水利枢纽的兴建对四大家鱼等产漂流性卵鱼类繁殖生态的影响. 1980s 以 来, 长江四大家鱼等产漂流性卵鱼类资源呈衰退现象. 2003-2006 年长江中游主要产漂流性卵鱼类的产卵 量 $143720 \times 10^{4}$ 粒 (尾) 与 $1970 \mathrm{~s}$ 相比, 种类减少了 10 余种. 其中四大家鱼产卵量为 $108069 \times 10^{4}$ 粒 (尾). 与蓄 水前相比, 长江中游四大家鱼产卵规模严重缩小, 4 年四大家鱼产卵总量为 1997-2002 年平均值的 $42.82 \%$, 为三峡蓄水前 2002 年的 $56.88 \%^{[16]}$. 已有调查表明 ${ }^{[17-21]}$, 目前长江四大家鱼等产漂流性卵鱼类已难以形成 产量, 在渔获物中比例已经很低, 这与四大家鱼等产漂流性卵鱼类产卵规模缩小是一致的. 四大家鱼等产漂 流性卵鱼类资源下降原因较多, 据相关报道 ${ }^{[22-26]}$, 在河流上建坝修闸, 改变河流水文情势, 改变现有生态环 境, 会对水文条件要求较高的四大家鱼繁殖群体产生更大负面影响, 是影响长江中下游四大家鱼等产漂流 性卵鱼类繁殖的主要原因.

3.3.2 过度捕捞 合理的捕捞能使鱼类资源再生产的过程得到保证, 资源永久利用. 但目前汉江上游汉中段 不合理捕捞严重,鱼类资源遭到破坏,资源量日趋衰竭. 一是沿江渔民普遍使用小网目的三层刺网和密瞑丝 网, 渔获物中经济鱼类的幼体占了很大比例, 近年来渔政部门对汉中水产品市场进行检查, $80 \%$ 的鲤鱼为 2 龄, 鲫鱼为 1 龄; 二是在一些鱼类重要栖息地洄游通道设置 “迷魂阵”; 三是电、炸、毒鱼履禁不止, 给汉江鱼 类资源造成了毁灭性破坏.

汉江流域渔具渔法一直在不断翻新, 特别是 1970s 末以来, 捕捞强度不断加大. 汉江上游较为传统的捕 捞渔具有刺网、三层刺网、百袋网、濠网、滚钩和卡子等, 1970s 末电捕和炸鱼等开始泛滥, 密眼网具使用越来 越普遍; 1990s 开始使用电拖网, 由于效益高, 发展很快. 随着捕捞强度加大, 鱼类资源量下降, 单船产量急剧 下降, 于是不断缩小网目、增大电拖网船的马力、提高电拖网电压. 根据调查, 电拖网目前网目多为 $1 \sim 2 \mathrm{~cm}$, 有的电拖网电压高达 1000 余 $\mathrm{V}$, 并开始采用多船联合作业. 高强度的捕捞对资源的破坏很严重, 特别是电 拖网, 捕捞没有选择性, 无论鱼大小, 一网打尽. 近 2 年来, 长江开始大规模春季禁渔, 汉江从 3 月 1 日- 6 月 30 日开始春季禁渔, 取得了很好的效果, 但解禁后, 为了补回休渔期的损失, 渔民变本加厉进行捕捞, 降低了 禁渔所取得的效果.

3.3.3 水质 丹江口以上三级区有排污口 161 处, 主要分布在汉江干流南阳、汉中、安康河段及濂水河、金钱 河等支流上. 汉江干流多处设有水质参评监测站点, 水质评价指标包括: 溶解氧、高镇酸盐指数、化学需氧 量、氨氮、挥发酚、总磷、 $\mathrm{pH}$ 值、五日生化需氧量、氟化物、 $\mathrm{As} 、 \mathrm{Cu} 、 \mathrm{~Pb} 、 \mathrm{Zn} 、 \mathrm{Cd}$ 和 $\mathrm{Cr}^{6+}$. 根据各测站全年期各指 标评价结果分析. 汉江上流干流总体水质较好, 以 II 类水体为主.

目前流域水资源质量总体良好,但仍存在以下问题 ${ }^{[27-30]}$ :

1) 面源污染问题相当突出. 丹江口库区及上游面源污染问题较为突出, 主要面源污染来源于暴雨期发 生的地面产流、径流会淋溶土壤中的氮、磷, 冲刷积存于土壤中的化学需氧量、氨氮等污染物, 随流域汇流进 人干流; 而农田面源、畜禽养殖和农村生活等农村面源污染也是汉江流域总氮和总磷负荷的主要来源之一.

2) 流域废污水排放量增长快、产业结构不尽合理. 汉江流域各地市社会经济发展很不均衡, 产业结构不 尽合理. 工业缺乏高新技术产业, 大多数的企业高能耗、重污染, 同时一些产值低、污染严重的乡镇企业和国 家明令禁止的小造纸、小化工等污染十分严重的“十五小”企业仍然存在, 这些企业污水排放严重污染了汉 江支流水质.

3) 水事法规不健全, 缺乏统一管理部门. 《水法》、《水污染防治法》在具体执行中, 存在着执法主体不 明、责任和义务不清等问题. 从流域层面上来讲, 保护水资源、防治水污染没有一个统一的具有权威性的部 门管理,且没有一套完整的、系统的规划,流域污染物总量控制缺少必要的实施方案.

4) 突发性水污染事故风险增大, 威胁用水安全. 汉江丹江口水库为南水北调中线工程水源地, 随着工业 和交通航运的日益发达, 各类潜在污染源、危险源也逐渐增多, 突发性水污染事故风险增大, 高危化学品、有 毒有机物的危害日益显著, 通常发生频率高、消除难度大, 且随机性和不确定性决定了在预防上也有很大的 难度, 直接威胁到饮水安全.

3.3.4 频繁的采砂活动 汉江干流主汛期非法采砂活动猖獗, 南水北调工程中线的汉江河道上违法违规开采 运输砂石的现象比比皆是, 汉江河道受到了严重的破坏和污染. 此外, 在汉江河道内挖砂运砂会造成汉江河 
水污染, 对汉江防洪能力造成影响, 对汉江生态的改变将很难恢复, 这些影响必然会对南水北调工程产生重 大阻碍.

究其根本, 是因为采砂、运砂已经形成牢固的利益链条, 与采砂的暴利比起来, 违规违法成本太低, 甚至 可以忽略不计. 面对巨大利益诱惑, 不断有人铤而走险、以身试法. 因此, 建议相关部门加大治理力度:

1)立即关闭、清理禁采区域内设置的采砂场点，包括汉江河道管理范围内所有的采砂设备、砂石料堆、 篮分料台、临建设施等.

2) 在加大清理的同时,尽快复平河道内弃土弃料, 整平河床滩面, 对有重大安全隐患的地带, 应设置醒 目的警示标志. 水利部门要加强河道巡查力度, 做好日常监督管理, 坚决查处河道非法采砂行为; 公安部门 要切实维护水上治安, 严厉打击阻扰、抗法等行为; 林业、环保部门要加强对湿地、自然保护区、饮用水源保 护区等范围内的生态环境保护, 加大执法力度, 配合进行全面清理; 国土、住管、交通、电力等部门要认真履 行各自职责,协同抓好禁止采砂工作.

3) 对违反规定的, 由沿汉江各县区人民政府组织有关行政部门依照有关规定依法查处,对构成犯罪的, 移交司法机关依法追究刑事责任.

4) 沿汉江各级有关部门要采取多种形式开展禁止采砂宣传工作,加大禁采法律、法规警示教育,并在重 点河段设立禁采公示牌、张贴禁采宣传标语, 畅通举报渠道,切实形成全社会共同参与、共同监督的良好氛 围,促进禁采工作取得实效.

致谢: 感谢十堰市郧县渔政站郑全洋站长、十堰市郧县水利水电局梁齐永在 2014 年早期资源野外监测过程 中提供帮助.

\section{4 参考文献}

[ 1 ] Borutsky EB, Wu XW, Bai GD et al. Hydrobiological survey of the region of the projected Dan Jiangkou reservoir with propositions for fisheries management. Acta Hydrobiologica Sinica, 1959: 33-56. [波鲁茨基 EB, 伍献文, 白国栋等. 丹 江口水库库区水生生物调查和渔业利用意见. 水生生物学集刊, 1959: 33-56.]

[ 2 ] Zhou CS, Liang ZX, Huang HN. Ecological features of the spawning of certain fishes in the Hanjiang River after the construction of dams. Acta Hydrobiologica Sinica, 1980, 7(2): 175-187. [周春生, 粱秩㸓, 黄鹤年. 兴修水利枢纽后汉 江产漂性卵鱼类的繁殖生态. 水生生物学集刊, 1980, 7(2): 175-187.]

[ 3 ] Yu ZT. Investigation on fish resources in the middle and lower reaches of Hanjiang river and the impaction of Danjiangkou project on fish resources. Reservoir Fisheries, 1982, 1: 2-13. [余志堂. 汉江中下游鱼类资源调查以及丹江口水利枢纽 对汉江鱼类资源影响的评价. 水库渔业, 1982, 1: 2-13.]

[ 4 ] Tang HY, Yu ZT, Liang ZX et al. A preliminary study on the sinking velocity and loss rate of drift eggs in Danjiangkou reservoir. Reservoir Fisheries, 1996, (4) : 25-27. [唐会元, 余志堂, 梁秩䑁等. 丹江口水库漂流性鱼卵的下沉速度 与损失率初探. 水利渔业, 1996, (4) : 25-27.]

[ 5 ] Changjiang Water Resources Commission of The Ministry of Water Resources ed. Comprehensive planning of the main stream of the Hanjiang river (In preparation). [长江水利委员会. 汉江干流综合规划(在编).]

[ 6 ] Zhang JM, He ZH eds. A manual for investigation of natural resources in inland waters. Beijing: Agricultural Press, 1991. [张觉民, 何志辉. 内陆水域渔业自然资源调查手册. 北京: 农业出版社, 1991.]

[ 7 ] Borutsky EB, Yu ZT, Liang ZX et al eds. GeZhouba and four famous Chinese carps in the Yangtze River. Wuhan: Hubei Science \& Technology Press, 1988. [易伯鲁, 余志堂, 梁秩㸓等. 葛洲坝水利枢纽与长江四大家鱼. 武汉: 湖北科学 技术出版社, 1988.]

[ 8 ] Survey team of spawning grounds of domestic fishes in Changjiang River ed. A survey on the spawning grounds of the four famous Chinese carps in the Changjiang River after dammed by the key water control project at GeZhouba. Journal of Fisheries of China, 1982, 6(4) : 287-305. [长江四大家鱼产卵场调查队. 葛洲坝水利枢纽工程截流后长江四大家鱼产 卵场调查. 水产学报, 1982, 6(4): 287-305.]

[ 9 ] Liu LH, Wu GX, Chao WX et al. Studies on the ecological effect on spawning of the black carp, the grass carp, the silver carp and the bighead carp in the Changjiang River after the constructions of the GeZhouba hydroelectric project. Acta Hydrobiologica Sinica , 1986, 10(2) : 353-364. [刘乐和, 吴国犀, 曹维孝等. 葛洲坝水利枢纽兴建后副青、草、鲢、 
鳙繁殖生态的研究. 水生生物学报, 1986, 10(2) : 353-364.]

[10] Liang ZX, Yi BL, Yu ZT. The reproductive habit and embryonic development of Elopichthys bambusa in Yangtze river. Acta Hydrobiologica Sinica, 1984, 8(4) : 389-404. [粱秩篓, 易伯鲁, 余志堂. 长江干流和汉江的鳡鱼繁殖习性及其 胚胎发育. 水生生物学集刊, 1984, 8(4): 389-404.]

[11] Meng QW. On the morphological characteristics of the larvae of seven species of freshwater fishes. Journal of Fisheries of China, 1982, 6(1) : 65-76. [孟庆闻. 7 种鱼类仔鱼的形态观察. 水产学报, 1982, 6(1) : 65-76. ]

[12] He XF, Song ZB, Xie EY. The breeding habits and embryonic development of long nose gudgeon (Saurogobio dabrui Bleeker) Journal of Southwest China Normal University: Natural Science, 1996, 21(3): 276-281. [柯学福、宋昭彬, 谢 恩义. 蛇鮈的产卵习性和胚胎发育. 西南师范大学学报: 自然科学版, 1996, 21(3) : 276-281.]

[13] Wang CX. The identification of the species in the "wild fry" of the middle waters of the Yangtze River. Acta Hydrobiologica Sinica , 1959: 315-343. [王昌篮. 长江中游“野鱼苗”的种类鉴定. 水生生物学集刊, 1959: 315-343.]

[14] Li XF, Huang DM, Xie WX et al. Current status of spawning grounds of fish with pelagic eggs in the middle reaches of Hanjiang River. Journal of DaLian Fisheries University, 2006, 21(2) : 105-111. [李修峰, 黄道明, 谢文星等. 汉江中 游产漂流性卵鱼类产卵场的现状. 大连水产学院学报, 2006, 21(2): 105-111.]

[15] Xie WX, Huang DM, Xie S et al. The early evolution of the four major Chinese carps resources in the middle and lower reaches of Hanjiang river after the construction and operation of Danjiangkou Reservoir. Journal of Hydroecology, 2009, 2 (2) : 44-49. [谢文星, 黄道明, 谢山等. 丹江口水利枢纽兴建后汉江中下游四大家鱼等早期资源及其演变. 水生 态学杂志, 2009, 2(2) : 44-49.]

[16] Duan XB, Chen DQ, Li ZH et al. Current status of spawning grounds of fishes with pelagic eggs in the middle reaches of the Yangtze River after impoundment of the Three Gorges Reservior. Journal of Fishery Sciences of China, 2008, 15(4) : 523-532. [段辛斌, 陈大庆, 李志华等. 三峡水库蓄水后长江中游产漂流性卵鱼类产卵场现状. 中国水产科学, $2008,15(4)$ : 523-532.]

[17] Liu JK, Cao WX. Fish resources of the Yangtze River basin and the tactics for their conservation. Resources and Environment in the Yangtze Valley, 1992, 1(1): 17-23. [刘建康, 曹文宣. 长江流域的鱼类资源及其保护对策. 长江流域资 源与环境, $1992, \mathbf{1}(1)$ : 17-23.]

[18] Peng QD. Research of impacts on four major Chinese carps spawning conditions by the Three Gorges Project [ Dissertation]. Beijing: China Institute of Water Resources and Hydropower Research, 2011. [彭期冬. 三峡工程对四大家鱼自 然繁殖条件影响研究 [学位论文]. 北京: 中国水利水电科学研究院, 2011.]

[19] Liu SP, Chen DQ, Duan XB et al. Monitoring of the four famous Chinese carps resources in the middle and upper reaches of the Yangtze River. Resources and Environment in the Yangtze Valley, 2004, 13(2) : 183-186. [刘绍平, 陈大庆, 段辛 斌等. 长江中上游四大家鱼资源监测与渔业管理. 长江流域资源与环境, 2004, 13(2)：183-186.]

[20] Qiu SL, Liu SP, Huang MG et al. Monitoring of spawning sites of four major Chinese carps in the middle section of Yangtze River. Acta Hydrobiologica Sinica, 2002, 26(6) : 716-718. [邱顺林, 刘绍平, 黄木桂等. 长江中游江段四大家鱼 资源调查. 水生生物学报, 2002, 26(6) : 716-718.]

[21] Liu SP, Duan XB, Chen DQ et al. Studies of status of fishery resources in the middle reach of the Yangtze River. Acta Hydrobiologica Sinica , 2006, 29(6) : 708-711. [刘绍平, 段辛斌, 陈大庆等. 长江中游渔业资源现状研究. 水生生 物学报, 2006, 29(6): 708-711.]

[22] Peng QD, Liao WG, Li C et al. Impacts of four major Chinese carps'natural reproduction in the middle reaches of Changjiang River by Three Gorges Project since the impoundment. Journal of SiChuan University: Engineering Science Edition, 2012, 44(2) : 228-232. [彭期冬, 廖文根, 李棚等. 三峡工程蓄水以来对长江中游四大家鱼自然繁殖影响研 究. 四川大学学报: 工程科学版, 2012, 44(2) : 228-232.]

[23] Li C, Peng J, Liao WG. Ecological hydrology factor analysis and ecological hydrology goals determine of Four Major Chinese Carps spawning in the middle reaches of the Changjiang River. Journal of China Institute of Water Resources and Hydropower Research, 2006, 4(3): 170-176. [李抌, 彭静, 廖文根. 长江中游四大家鱼发江生态水文因子分析及生态 水文目标确定. 中国水利水电科学研究院学报, 2006, 4(3): 170-176.]

[24] Xu CS, Ai ZQ, Xiao M. A review of influencing factors on natural reproduction of four major Chinese carps Yangtze River. Journal of China Three Gorges University: Natural Sciences, 2017, 39(4) : 27-30. [许承双, 艾志强, 肖鸣. 影响长江四 大家鱼自然繁殖的因素研究现状. 三峡大学学报：自然版, 2017, 39(4) : 27-30.] 
[25] Wang S, Liao WG, Chen DQ et al. Analysis of eco-hydrological characteristics of the four Chinese farmed carps' spawning grounds in the middle reach of the Yangtze River. Resources and Environment in the Yangtze Valley, 2008, 17(6): 892897. [王尚, 廖文根, 陈大庆等. 长江中游四大家鱼产卵场的生态水文特性分析. 长江流域资源与环境, 2008, 17 (6) : 892-897.]

[26] Li J, Xia ZQ, Wang YK et al. Study on river morphology and flow characteristics of four major Chinese carps spawning grounds in the middle reach of the Yangtze River. Journal of SiChuan University: Engineering Science Edition, 2010,42 (4) : 63-70. [李建, 夏自强, 王远坤等. 长江中游四大家鱼产卵场河段形态与水流特性研究. 四川大学学报: 工 程科学版, 2010, 42(4): 63-70.]

[27] Ma ZJ. Survey on the water pollution and harnessing of the middle and upper reaches of Hanjing river. Journal of Hanzhong Teachers College: Natural Science, 2001, 19(1): 86-90. [马征杰. 对汉江中上游水环境污染的调查及思考. 汉中师 范学院学报: 自然科学, 2001, 19(1): 86-90.]

[28] Zhang CL, Li YN. Present situation of water quality and protecting countermeasures for the Dan-Hanjiang River basin in Shanxi Province. Joural of Water Resources \& Water Engineering, 2007, 18(3)：87-90. [ 张春玲, 李娅妮. 陕西省丹汉 江流域水质现状及防护对策. 水资源与水工程学报, 2007, 18(3): 87-90.]

[29] Liu DY, Wang H, Jiang Y et al. Water pollution control schemes for upstream of Hanjiang river. Earth Science Journal of China University of Geosciences, 2000, 25(5): 487-491. [刘大银, 汪翰, 蒋艳等. 汉江上游重点保护水源污染控制 方案研究. 地球科学中国地质大学学报, 2000, 25(5) : 487-491.]

[30] Zhao ZP, Yan S, Tong YA et al. Eco-environmental status assessment and countermeasures in the upper Hanjiang river basin. Bulletin of Soil and Water Conservation, 2012, 32(5):32-60. [ 赵佐平, 间莎, 同延安等. 汉江流域上游生态环 境现状及治理措施. 水土保持通报, 2012, 32(5) : 32-60.] 